\title{
Health effects and standard threshold shift among workers in a noisy working environment ${ }^{*}$
}

\author{
Penpatra Sripaiboonkij $^{1 \#}$, Savitree Chairut $^{2}$, Adul Bundukul $^{2}$ \\ ${ }^{1}$ Faculty of Public Health, Thammasat University, Bangkok, Thailand; *Corresponding Author: sripaiboonkijpor@hotmail.com \\ ${ }^{2}$ Nopparat Rajathanee Hospital, Bangkok, Thailand
}

Received 22 April 2013; revised 23 May 2013; accepted 15 June 2013

Copyright (C) 2013 Penpatra Sripaiboonkij et al. This is an open access article distributed under the Creative Commons Attribution License, which permits unrestricted use, distribution, and reproduction in any medium, provided the original work is properly cited.

\begin{abstract}
Introduction: Working in a noisy environment is a risk for employee hearing health. Standard threshold shift (STS) can be used as a screening method to detect early indications of hearing deterioration. Objective: To investigate health effects related to STS in motor compressor workers. Methods: A cross sectional study of 464 motor compressor workers was conducted including hearing health examination by audiometer, and noise level in the workplace was monitored. Workers who reported having hobbies relating to noise, e.g. gun shooting, or a personal history of disease relating to the ear were excluded. The relationship between health effects and workers with STS was studied. Results: There were more men $81.90 \%$ (aged range 31 - 40 years old) than women working for the company. The average continuous noise level in the workplace was $84.14 \pm 5.21 \mathrm{~dB}(\mathrm{~A})$. The study showed that working at the factory for more than 14 years (OR= $3.84,95 \% \mathrm{Cl} 1.54-9.56)$ and being exposed to noise at least 8 hours a day (OR $=2.12,95 \% \mathrm{Cl}=1.02-4.40$ ) effected to STS. Workers with STS showed significant communication difficulties $(\mathrm{OR}=1.89,95 \% \mathrm{Cl}=1.03$ 3.49) and stress/nausea more than workers with-

\footnotetext{
"“What this paper adds" Standard threshold shift (STS) could be used as a technique to screen a person who has a hearing problem as it defines a change in the hearing threshold relative to a baseline audiogram of an average of $10 \mathrm{~dB}$ or more at $2 \mathrm{kHz}, 3 \mathrm{kHz}$, or $4 \mathrm{kHz}$ in either ear. People exposed to high noise levels for extended durations of time may be affected to health and STS although symptoms are non-specified. From previous study, there is no paper related to STS and working in a noisy environment. So, this paper is worthwhile for publication. Competing interests: None.

Patient consent: Obtained.

Contributor statement: Conceived and designed the experiments: PS, SC,AB; Performed the experiments: PS, SC; Analyzed the data: PS, SC Wrote the paper: PS, SC, AB.
}

out STS (OR $=1.54,95 \% \mathrm{Cl}=0.90-2.65)$ although not statistically significant. Conclusions: Workers exposed to continuous noise in the motor compressor industry are at risk of STS. Duration of exposure to noise is a key factor in respect of harm to hearing health. STS could be used as a tool to screen workers who have hearing health problems.

Keywords: Standard Threshold Shift; STS; Health Effects; Motor Compressor; Noise

\section{INTRODUCTION}

Occupational noise exposure and noise-induced hearing loss (NIHL) have been recognized as classical problem among workers working in industries. NIHL occurs due to hair cell damaged which is irreversible. NIHL is generally observed to affect a person's hearing sensitivity at higher frequencies, especially at $4000 \mathrm{~Hz}$ [1]. When workers are exposed to noise, it is difficult to detect NIHL symptoms or health related NIHL until symptom manifests. So, screening tests will be useful to detect any early symptoms and to prevent problems from worsening.

A screening test is a preliminary test purposed to prevent occupational diseases. Standard threshold shift (STS) could be used as a technique to screen a person who has a hearing problem as it defines a change in the hearing threshold relative to a baseline audiogram of an average of $10 \mathrm{~dB}$ or more at $2 \mathrm{kHz}, 3 \mathrm{kHz}$, or $4 \mathrm{kHz}$ in either ear [1]. It is therefore different from noise induced hearing loss (NIHL) because the baseline will change in both ears.

People exposed to high noise levels for extended durations of time may be affected to health and STS although symptoms are non-specified.

Workers in a motor compressor factory exposed to continuous noise for 8 hours or more per day at noise 
levels ranging from 80 - $90 \mathrm{~dB}(\mathrm{~A})$ were at risk of noise induce hearing loss and STS. Health effects could be presented in a worker who has STS.

In the present study, workers in a motor compressor factory have been employed to participate in the project purposed to study the association between 1) exposure to noise and STS, and 2) workers who experience STS and health effects.

\section{MATERIALS AND METHODS}

\subsection{Study Design and Setting}

A cross sectional study was conducted in March-April 2011 at a motor compressor factory. The factory produced compressors for fridges and parts for air conditioners. Processes of motor compressor production shown in Appendix 1.

Of 464 workers, those who had been working for the company for at least 6 months and had results from hearing tests take over the past 2 consecutive years were selected to participate the project.

Secondary data for hearing tests carried out by audiometer on workers over the past 2 years were used to study STS, self-administered questionnaire, and noise level measurements were also used in the study. Most of the workers have only a day shift that runs for about 12 hours (routine work 8 hours and overtime 4 hours), and the workers spent 8 - 12 hours working in a noisy environment.

Subjects were excluded if they had hobbies or habits related to noise, e.g. disco pub, shooting, or those with personal diseases e.g. tuberculosis, mumps or any previous ear related accidents. Workers who showed a change in hearing threshold relative to a baseline audiogram of an average of $10 \mathrm{~dB}$ or more at $2 \mathrm{kHz}, 3 \mathrm{kHz}$, or $4 \mathrm{kHz}$ in either ear were defined as a worker with STS. The example of STS calculation was shown in Appendix 2.

Participants were provided with assurances of confidentiality and the objectives of the study were explained and an informed consent form was signed prior to administering the questionnaire. The study was approved by the Ethics Committee of the Faculty of Medicine, Srinakharinwirot University, Thailand.

\subsection{Questionnaire}

Of 464 workers were asked to do self-administered questionnaire. They were asked about personal information, work history, health status, behaviour on using personal protective equipment, hobbies and health effects of exposure to noise in the workplace.

\subsection{Noise Monitoring}

Noise levels in a motor compressor factory were meas- ured by sound level meter model sound track LXT\#1 serial number 0001029.

The level of noise was measured for each production process. The sound level meter was calibrated before sampling using a calibrator model Larson Davis model CAL 250 \# 2820.

The pattern of noise level monitoring in the workplace is shown in Appendix 3.

\subsection{Data Analysis}

Statistical Analysis of data was carried out using SPSS. Descriptive analysis was used to describe characteristic of study populations, work duration, duration of noise exposure in each day and the levels of noise in the workplace.

Binary regression analysis was used to study the association between change of STS baseline and personal factors, duration of exposure to noise, work duration for the company, and association between STS and health effects. Workers with STS and heath symptoms e.g. headache/dizzy, stress/nausea, loss of concentration and difficulty in communication were studied. Adjusted odds ratios, 95\% CI were reported.

\section{RESULTS}

\subsection{Population Characteristics}

The study population consisted of 464 workers aged between 20 - 60 years who had completed an audiogram examination over the past 2 years and were not exposed to excessive noise as a result of hobbies or ear related disease.

The study population consisted mainly of men aged 21 - 40 years and most of them had been working in the factory less than 5 years. Most the participants worked for the company 1 - 5 years and were exposed to noise more than 8 hours per day. The education levels of workers were primary school level and vocational or college level. The characteristic of participants is shown in Table $\mathbf{1 .}$

\subsection{Noise Levels in the Workplace}

The present study monitored noise levels in the workplace by sound level meter. The highest noise level in the workplace was $97 \mathrm{~dB}(\mathrm{~A})$ and the lowest noise level was $66 \mathrm{~dB}(\mathrm{~A})$. The average noise level in the production department was $84.14 \pm 5.21 \mathrm{~dB}(\mathrm{~A})$. Workers were exposed to noise in the workplace more than 8 hours per day. The noise levels on the production line are shown in Table 2.

\subsection{Relationship between Personal Factors and STS}

Hearing examination results showed STS among 51 
Table 1. Characteristics of study population.

\begin{tabular}{|c|c|c|}
\hline Characteristics & N (464) & $\%$ \\
\hline \multicolumn{3}{|l|}{ Sex } \\
\hline Male & 380 & 81.90 \\
\hline Female & 84 & 18.10 \\
\hline \multicolumn{3}{|l|}{ Age } \\
\hline Less than 21 years & 16 & 3.45 \\
\hline 21 - 30 years & 157 & 33.84 \\
\hline 31 - 40 years & 193 & 41.59 \\
\hline 41 - 50 years & 82 & 17.67 \\
\hline 51 - 60 years & 16 & 3.45 \\
\hline \multicolumn{3}{|l|}{ Education } \\
\hline Secondary school or lower & 185 & 39.87 \\
\hline High school & 258 & 55.60 \\
\hline Bachelor or higher university degree & 21 & 4.53 \\
\hline \multicolumn{3}{|l|}{ Noise exposure in one day } \\
\hline Less than 2 hours & 60 & 12.93 \\
\hline 8 hours & 105 & 22.63 \\
\hline $10-12$ hours & 199 & 42.89 \\
\hline $13-16$ hours & 100 & 21.55 \\
\hline \multicolumn{3}{|l|}{ work duration for the factory } \\
\hline $1-5$ years & 257 & 54.74 \\
\hline $6-10$ years & 54 & 11.64 \\
\hline 11 - 15 years & 54 & 11.42 \\
\hline $16-20$ years & 53 & 11.42 \\
\hline Equal or more than 21 years & 46 & 10.78 \\
\hline
\end{tabular}

Table 2. Noise levels on the production line.

\begin{tabular}{cccc}
\hline Department & Noise level (Leq) & Min. dB (A) & Max. dB (A) \\
\hline Department \#1 & 86 & 79 & 88 \\
Department \#2 & 91 & 87 & 94 \\
Department \#3 & 86 & 83 & 97 \\
Department \#4 & 83 & 67 & 87 \\
Department \#5 & 83 & 81 & 85 \\
Maintenance & 86 & 84 & 88 \\
Engineering & 74 & 66 & 82 \\
Average \pm SD & $84.14 \pm 5.21$ & & \\
\hline
\end{tabular}

workers. Binary regression analysis showed a statistically significant risk of STS for workers who had worked for the company for at least 14 years (Adj OR $=3.84$, $95 \% \mathrm{CI}=1.54-9.56$ ) or have been exposed to noise for more than 8 hours a day (Adj OR $=2.12,95 \% \mathrm{CI}=1.02$ 4.40). Workers aged 40 years old and above did not show significant risk of STS compared to workers aged below 40 (Adj OR $=2.04,95 \% \mathrm{CI}=0.98-4.27$ ). Production workers were at risk of STS although this was not statistically significant compared to engineers (Adj OR $=4.00$, $95 \% \mathrm{CI}=0.91$ - 17.52). Education level, marriage status, and department did not have a statistically significant influence on STS. The results are shown in Table 3.

\subsection{Health Effect and Change of STS}

Workers that reported STS were selected to study any related health effects of STS and analysed by logistic regression analysis. The relationship between workers with STS and health effects presented headaches/dizziness (Adj. OR1.78, 95\%CI $=0.50-6.32$ ), stress/nausea $(1.54,95 \% \mathrm{CI}=0.90-2.65)$ and loss of concentration $(0.60,95 \% \mathrm{CI}=0.30-1.21)$ but this was not found to be significant compared to workers without STS. Workers with STS showed they had statistically significant communication difficulties compared to workers without STS $(1.98,95 \%$ CI $=1.03-3.49)$, data shown in Table 4.

Health effects of workers with STS were also studied when they were not at work. The results showed that workers with STS had no significant health effects while not at work compared to workers without STS. However, workers with STS presented headaches/ dizziness (Adj. $\mathrm{OR}=2.95,95 \% \mathrm{CI}=0.84-10.42$ ), stress/nausea (Adj. $\mathrm{OR}=1.25,95 \% \mathrm{CI}=0.58-2.68)$ and communication difficulties (Adj. OR 1.30, 95\%CI $=0.59-2.86$ ) while they were off work. The results are shown in Table 5.

\section{DISCUSSION}

The questionnaire had a high response rate and audiogram data from physical examinations conducted by the factory was available for the past 2 years. This data was then used to calculate STS and the noise levels in the workplace were monitored while the research was taking place. Given the information and data available bias in this study is considered unlikely.

The present study found a correlation between health effects related to STS and exposure to noise for duration of 8 or more hours a day. The data reveals interesting health effects between workers with STS compared with workers without STS, although the health effects were generally nonspecific and therefore could be linked to other conditions. 
Table 3. Personal factors and adjusted odd ratios relating to STS.

\begin{tabular}{|c|c|c|c|c|}
\hline \multirow{3}{*}{ Personal factors } & \multicolumn{2}{|c|}{ STS } & \multirow{3}{*}{ Crude odds ratio(95\%CI) } & \multirow{3}{*}{ Adjusted odds ratio(95\%CI) } \\
\hline & Yes & No & & \\
\hline & n (\%) & n (\%) & & \\
\hline \multicolumn{5}{|l|}{$\operatorname{Sex}^{1}$} \\
\hline Female & $7(8.33)$ & 77(91.67) & 1 & 1 \\
\hline Male & $44(11.58)$ & $336(88.42)$ & $1.44(0.63-3.32)$ & $1.22(0.50-2.94)$ \\
\hline \multicolumn{5}{|l|}{ Age $^{2}$} \\
\hline Less than 40 years & $25(7.42)$ & 312(92.58) & 1 & 1 \\
\hline 40 years up & $26(20.47)$ & 101(79.53) & $3.21(1.78-5.81)$ & $2.04(0.98-4.27)$ \\
\hline \multicolumn{5}{|l|}{ Marriage status $^{1}$} \\
\hline Married & $11(7.91)$ & 128(92.09) & 1 & 1 \\
\hline Single/separated & $40(12.31)$ & 285(87.69) & $1.63(0.81-3.29)$ & $0.93(0.43-2.02)$ \\
\hline \multicolumn{5}{|l|}{ Education level $^{1}$} \\
\hline Bachelor degree & $5(23.81)$ & 16(76.19) & 1 & 1 \\
\hline High school & $24(9.30)$ & $234(90.70)$ & $1.32(0.71-2.43)$ & $0.863(0.45-1.67)$ \\
\hline Lower than high school & 22(11.89) & 163(88.11) & $0.43(0.14-1.30)$ & $0.335(0.10-1.17)$ \\
\hline \multicolumn{5}{|l|}{ Department $^{3}$} \\
\hline Engineering/maintenance & 2(3.08) & 63(96.92) & 1 & 1 \\
\hline Production & $49(12.28)$ & $350(87.72)$ & $4.41(1.05-18.60)$ & $4.00(0.91-17.52)$ \\
\hline \multicolumn{5}{|l|}{ Work duration $^{4}$} \\
\hline Less than 4 years & $10(4.08)$ & 235(95.92) & 1 & 1 \\
\hline $4-13$ years & $17(17.35)$ & 81(82.65) & $1.18(0.59-2.35)$ & $0.82(0.37-1.80)$ \\
\hline Equal or more than 14 years & 24(19.83) & $97(80.17)$ & $5.81(2.68-12.62)$ & $3.84(1.54-9.56)$ \\
\hline \multicolumn{5}{|l|}{ Noise exposure in a day ${ }^{5}$} \\
\hline 1 - 8 hours & 28(15.38) & $154(84.62)$ & 1 & 1 \\
\hline More than 8 hours & $23(8.16)$ & 259(91.84) & $2.16(1.08-4.34)$ & $2.12(1.02-4.40)$ \\
\hline
\end{tabular}

${ }_{1}^{1}$ effect estimate adjusted for: age, department, work duration , noise exposure in a day; ${ }^{2}$ effect estimate adjusted for: department, work duration , noise exposure in a day; ${ }^{3}$ effect estimate adjusted for: age, work duration , noise exposure in a day; ${ }^{4}$ effect estimate adjusted for: age, department, noise exposure in a day; 5 effect estimate adjusted for: age, department, work duration.

Table 4. The association between health effects and STS while workers in the workplace.

\begin{tabular}{|c|c|c|c|c|c|c|c|c|c|c|c|c|}
\hline \multirow[t]{2}{*}{ STS } & \multicolumn{3}{|c|}{ Headache/dizziness $^{1}$} & \multicolumn{3}{|c|}{ Stress/nausea ${ }^{1}$} & \multicolumn{3}{|c|}{ Loss of concentration $^{1}$} & \multicolumn{3}{|c|}{ Communication difficulties $^{1}$} \\
\hline & $\begin{array}{c}\text { Yes } \\
\text { n (\%) }\end{array}$ & $\begin{array}{c}\text { No } \\
\text { n (\%) }\end{array}$ & $\begin{array}{c}\text { Adj.OR, } \\
95 \% \text { CI }\end{array}$ & $\begin{array}{c}\text { Yes } \\
\text { n (\%) }\end{array}$ & $\begin{array}{c}\text { No } \\
\text { n (\%) }\end{array}$ & $\begin{array}{c}\text { Adj.OR, } \\
95 \% \mathrm{CI}\end{array}$ & $\begin{array}{c}\text { Yes } \\
\text { n (\%) }\end{array}$ & $\begin{array}{c}\text { No } \\
\text { n (\%) }\end{array}$ & $\begin{array}{c}\text { Adj.OR, } \\
95 \% \text { CI }\end{array}$ & $\begin{array}{c}\text { Yes } \\
\text { n (\%) }\end{array}$ & $\begin{array}{c}\text { No } \\
\text { n (\%) }\end{array}$ & $\begin{array}{c}\text { Adj.OR, } \\
95 \% \text { CI }\end{array}$ \\
\hline No & $48(10.71)$ & $\begin{array}{c}400 \\
(89.29)\end{array}$ & 1 & $\begin{array}{c}41 \\
(11.33)\end{array}$ & $\begin{array}{c}321 \\
(88.67)\end{array}$ & 1 & $\begin{array}{c}47 \\
(12.67)\end{array}$ & $\begin{array}{c}324 \\
(87.33)\end{array}$ & 1 & $\begin{array}{c}42 \\
(10.55)\end{array}$ & $\begin{array}{c}356 \\
(89.45)\end{array}$ & 1 \\
\hline yes & $\begin{array}{c}3 \\
(18.75)\end{array}$ & $\begin{array}{c}13 \\
(81.25)\end{array}$ & $\begin{array}{c}1.78 \\
(0.50-6.32)\end{array}$ & $\begin{array}{c}10 \\
(9.80)\end{array}$ & $\begin{array}{c}92 \\
(90.20)\end{array}$ & $\begin{array}{c}1.54 \\
(0.90-2.65)\end{array}$ & $\begin{array}{c}4 \\
(4.30)\end{array}$ & $\begin{array}{c}89 \\
(95.70)\end{array}$ & $\begin{array}{c}0.60 \\
(0.30-1.21)\end{array}$ & $\begin{array}{c}9 \\
(13.64)\end{array}$ & $\begin{array}{c}57 \\
(86.36)\end{array}$ & $\begin{array}{c}1.89 \\
(1.03-3.49)\end{array}$ \\
\hline
\end{tabular}

${ }^{1}$ effect estimate adjusted for: age, department, work duration, noise exposure in a day, noise level, frequently used hearing protection, PPE hygiene, and PPE shared. 
Table 5. The association between health effects and STS while workers outside the workplace.

\begin{tabular}{|c|c|c|c|c|c|c|c|c|c|c|c|c|}
\hline \multirow[t]{2}{*}{ STS } & \multicolumn{3}{|c|}{ Headache/dizziness ${ }^{1}$} & \multicolumn{3}{|c|}{ Stress/nausea ${ }^{1}$} & \multicolumn{3}{|c|}{ Loss of concentration $^{1}$} & \multicolumn{3}{|c|}{ Communication difficulties ${ }^{1}$} \\
\hline & $\begin{array}{l}\text { Yes } \\
\text { n (\%) }\end{array}$ & $\begin{array}{c}\text { No } \\
\text { n (\%) }\end{array}$ & $\begin{array}{l}\text { Adj.OR, } \\
95 \% \text { CI }\end{array}$ & $\begin{array}{l}\text { Yes } \\
\text { n (\%) }\end{array}$ & $\begin{array}{l}\text { No } \\
\text { n (\%) }\end{array}$ & $\begin{array}{l}\text { Adj.OR, } \\
95 \% \text { CI }\end{array}$ & $\begin{array}{c}\text { Yes } \\
\text { n (\%) }\end{array}$ & $\begin{array}{c}\text { No } \\
\text { n (\%) }\end{array}$ & $\begin{array}{l}\text { Adj.OR, } \\
\text { 95\% CI }\end{array}$ & $\begin{array}{c}\text { Yes } \\
\text { n (\%) }\end{array}$ & $\begin{array}{c}\text { No } \\
\text { n (\%) }\end{array}$ & $\begin{array}{l}\text { Adj.OR, } \\
95 \% \text { CI }\end{array}$ \\
\hline No & $\begin{array}{c}49 \\
(11.14)\end{array}$ & $\begin{array}{c}391 \\
(88.86)\end{array}$ & 1 & $\begin{array}{c}44 \\
(10.89)\end{array}$ & $\begin{array}{c}360 \\
(89.11)\end{array}$ & 1 & $\begin{array}{c}48 \\
(10.74)\end{array}$ & $\begin{array}{c}399 \\
(89.26)\end{array}$ & 1 & $\begin{array}{c}44 \\
(11.22)\end{array}$ & $\begin{array}{c}348 \\
(88.78)\end{array}$ & 1 \\
\hline yes & $\begin{array}{c}2 \\
(8.33)\end{array}$ & $\begin{array}{c}22 \\
(91.67)\end{array}$ & $\begin{array}{c}2.95 \\
(0.84-10.42)\end{array}$ & $\begin{array}{c}7 \\
(11.67)\end{array}$ & $\begin{array}{c}53 \\
(88.33)\end{array}$ & $\begin{array}{c}1.25 \\
(0.58-2.68)\end{array}$ & $\begin{array}{c}3 \\
(17.65)\end{array}$ & $\begin{array}{c}14 \\
(82.35)\end{array}$ & $\begin{array}{c}0.57 \\
(0.13-2.59)\end{array}$ & $\begin{array}{c}7 \\
(9.72)\end{array}$ & $\begin{array}{c}65 \\
(90.27)\end{array}$ & $\begin{array}{c}1.30 \\
(0.59-2.86)\end{array}$ \\
\hline
\end{tabular}

1 effect estimate adjusted for: age, department, work duration, noise exposure in a day, noise level, frequently used hearing protection, PPE hygiene, and PPE shared.

Some studies show an association between noise exposure and hypertension, impaired fasting glucose and diabetes even when the noise level was not high [2,3]. Our study confirmed workers within a noisy environment are at risk of STS and related headache/nausea, stress/ dizziness, loss of concentration and having communication difficulties.

Most workers in the motor compressor factory were men because the factory is related to auto part assembly and the parts are quite heavy. The study showed that workers with low education were more susceptible to STS than workers with high education. This may because workers with high degrees can choose jobs with more favourable working conditions while workers with low education cannot.

\subsection{Factors Related to STS}

Previous studies showed factors related to hearing loss are duration of exposure to noise, cigarette smoking and noise levels in the workplace [4-7]. Long durations of exposure to noise have been shown to damage hair cells and continued exposure to noise could lead to irreversible hair cell damage. Accordingly, workers frequently exposed to noise should be provided with noise hearing protection.

From the study, gender does not appear to be an influential factor of developing STS although it should be noted, most the workers in the motor compressor factory were men. While education level was not a statistically significant factor relating to STS this may be because the participants had graduated from primary school and high school or vocational courses and few of them had a high level of education. As above duration of exposure to noise in the workplace appeared to influence STS in workers consistent with the fact STS is a typical occupational problem among workers in a noisy environment. Workers in noisy environments invariably present noise induced hearing loss [8-12].

\subsection{Health Effects Due to STS}

The study demonstrates an impact from noise on health both inside and outside the work place. The im- pact of noise on health was significant for workers exposed to noise for long durations which is not surprising because noise has been found to cause noise induced hearing loss and harm hair cells in previous studies.

Workers exposed to noise for more than 8 hours a day or who worked in the factory for more than 14 years show a significant risk of health effects. The company should therefore have a noise hearing conservation programme for those employees who are exposed to noise for long durations or work at the factory for a long period of time even if symptoms are not yet considered serious due to the likelihood symptoms will worsen over time.

Workers with STS reported heath symptoms, e.g. headache, dizziness, or nausea. These workers were exposed to noise more than 8 hours a day. Such workers may have to shout due to hearing problems and noise in the work place creating additional difficulties in their environment which could lead to stress. Although not statistically significant it is also worth noting symptoms reported by workers exposed to shorter durations of noise (i.e., less than 8 hours per day). This may indicate even shorter durations of exposure to noise can be harmful to health. Indeed, ISO Models predicted exposure to noise from 10 years could be harmful to hearing health [13].

Hearing health may be affected by exposure to either high noise level or continuous noise level. Regression analysis showed an association between STS and noise exposure, and STS and health effects such as stress/ nausea and communication problems.

From previous studies, workers in a noisy environment suffered from annoyance, sleeping disturbance, stress, depression, and fatigue adversely affecting quality of life [14-16].

Regression analysis showed a positive correlation between duration of exposure to noise and negative health effects. One potential solution would be to operate a rota system where employees spend less hours in a noisy environment in addition to being provided with PPE at work. Previous studies showed workers exposed to noise often manifests as hypertension, tachycardia, increased cortisol release and increased physiologic stress $[17,18]$. Results from this study are consistent with previous studies that exposure to noise can have adverse effects on 
health and STS screening would be a useful indicator for early detection.

Workers who have been diagnosed with STS will benefit from early detection if they are transferred to work in environments where there is less noise.

STS Screening tests will help increase workers awareness of related health effects which may motivate them to wear the correct protective safety equipment.

\subsection{Limitations of the Study}

The number of workers suffering adverse health effects due to STS was lower than expected but this may be due to a healthy worker effect bias.

\section{CONCLUSION}

Working in a noisy environment is thought to put workers at risk of STS and related health problems. STS screening tests will be beneficial for employee health as it will provide an opportunity to identify those affections and to take the necessary steps to prevent further deterioration and the resulting negative health effects. Workers exposed to noise for more than 8 hours a day should be provided with appropriate hearing protection.

\section{ACKNOWLEDGEMENTS}

Thanks to all workers, production manager and safety officer who supported and participated the project.

\section{REFERENCES}

[1] Occupational Safety \& Health Administration (2002) Hearing conservation. 2007.

http://www.osha.gov/Publications/OSHA3074/osha3074. $\underline{\mathrm{html}}$

[2] Cheng, T., Liu, C., Huang, K., Chen, R., Lai, J. and Bao, B. (2001) High frequency hearing loss, occupational noise exposure and hypertension: A cross sectional study in male workers. Environmental Health, 10, 35-42. doi:10.1186/1476-069X-10-35

[3] Jang, T., Kim, B., Kwon, Y. and Im, H. (2011) The association between impaired fasting glucose and noise induce hearing loss. Journal of Occupational Health, 53, 274-279. doi:10.1539/joh.10-0073-OA

[4] Mizoue, T., Miyamoto, T. and Shimizu, T. (2003) Combined effect of smoking and occupational exposure to noise on hearing loss in steel factory workers. Occupational and Environmental Medicine, 60, 56-59. doi:10.1136/oem.60.1.56

[5] Ferrite, S. and Santana, V. (2005) Joint effects of smoking, noise exposure and age on hearing loss. Occupational Medicine, 55, 48-53. doi:10.1093/occmed/kqi002

[6] Uchida, Y., Nakashimat, T., Ando, F., Niino, N. and Shimokata, H. (2005) Is there a relevant effect of noise and smoking on hearing? A population-based aging study. In- ternational Journal of Audiology, 44, 86-91. doi:10.1080/14992020500031256

[7] Attarchi, M.S., Sadeghi, Z., Dehghan, F., Sohrabi, M.M. and Mohammadi, S. (2010) Assessment of hearing standard threshold shift based on audiometric findings in steel company workers. Iranian Red Crescent Medical Journal, 12, 644-649.

[8] Ologe, F.E., Olajide, T.G., Nwawolo, C.C. and Oyejola, B.A. (2008) Deterioration of noise-induced hearing loss among bottling factory workers. Journal of Laryngology and Otology, 122, 786-794. doi:10.1017/S0022215107000242

[9] Picarda, M., Girardb, S., Simardb, M., Larocqueb, R., Lerouxa, T. and Turcottec, F. (2008) Association of workrelated accidents with noise exposure in the workplace and noise-induced hearing loss based on the experience of some 240,000 person-years of observation. Accident Analysis and Prevention, 40, 1644-1652. doi:10.1016/j.aap.2008.05.013

[10] Dhere, A.M., Pawar, C.B., Patil, D.A. and Pawar, J.A. (2009) Noise induced hearing loss (NIHL) in saw mill and printing press workers in Akluj Town of Solapur district. Journal of Environmental Sciences, 51, 187-190.

[11] Henderson, E., Testa, M.A. and Hartnick C. (2011) Prevalence of noise-induced hearing-threshold shifts and hearing loss among US youths. Pediatrics, 127, 39-46. doi:10.1542/peds.2010-0926

[12] Leensen, M., van Duivenbooden, J. and Dreschler, W. (2011) A retrospective analysis of noise-induced hearing loss in the Dutch construction industry. International Archives of Occupational Environmental Health, 84, 577-590.

[13] ISO (1999) Acoustic-determination of occupational noise exposure and estimation of noise- induced hearing impairment. 2nd Edition, International Organisation for Standardization, Geneva.

[14] Canton, K. and Williams, W. (2012) The consequences of noise-induced hearing loss on dairy farm communities in New Zealand. Journal of Agromedicine, 17, 354-363. doi:10.1080/1059924X.2012.713840

[15] Eysel-Gosepath, K., Daut, T., Pinger, A., Lehmacher, W. and Erren T. (2012) Effects of noise in primary schools on health facets in German teachers. Noise Health, 14, 129-134.

[16] Kim, M., Chang, S., Seong, J., Holt, J., Park, T., Ko, J. and Croft, J. (2012) Road traffic noise: Annoyance, sleeping disturbance, and public health implications. American Journal of Preventive Medicine, 43, 353-360. doi:10.1016/j.amepre.2012.06.014

[17] Sokas, R.K., Moussa, M.A., Gomes, J., Anderson, J.A., Achuthan, K.K., Thain, A.B. and Abu Risheh, Z. (1995) Noise-induced hearing loss, nationality, and blood pressure. American Journal of Industrial Medicine, 28, 281288. doi:10.1002/ajim.4700280212

[18] Seidman, M.D. and Standring, R.T. (2010) Noise and quality of life. International Journal of Environmental Research and Public Health, 7, 3730-3738. doi:10.3390/ijerph7103730 


\section{Appendix 1}

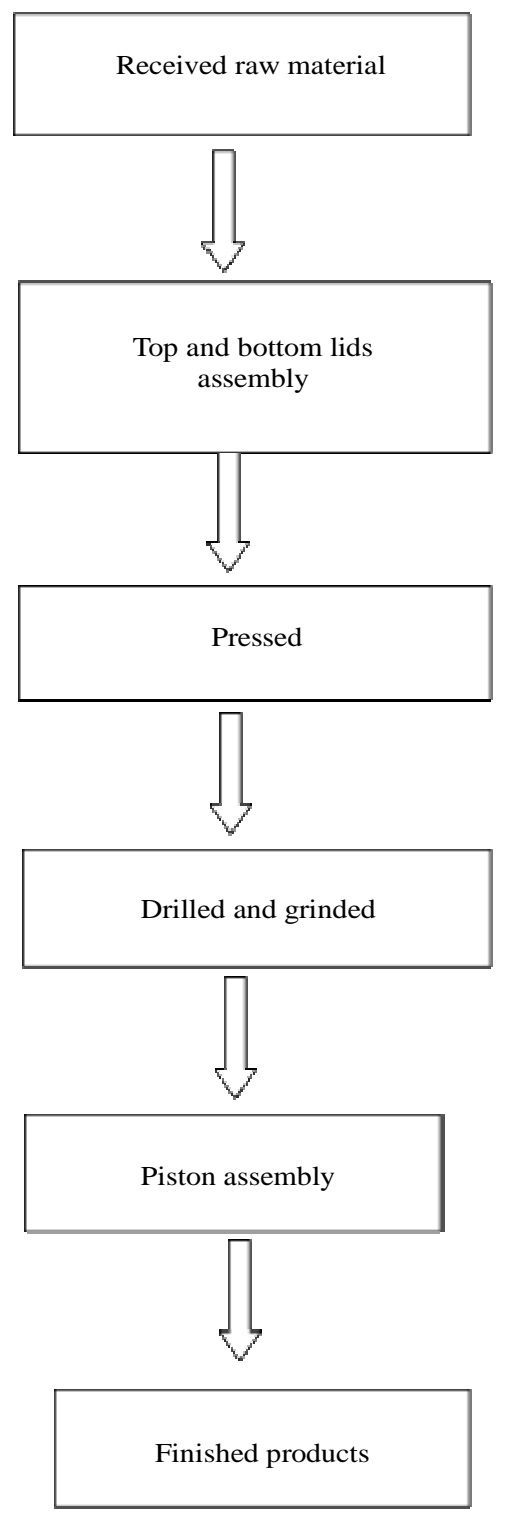

Figure 1. Processes of motor compressor production.

\section{Appendix 2}

\begin{tabular}{lccc}
\hline $\begin{array}{l}\text { Example (showing only frequencies relevant to STS } \\
\text { determination) }\end{array}$ & $\mathbf{2} \mathbf{~ K H z}$ & $\mathbf{3} \mathbf{~ K H z}$ & $\mathbf{4 ~ K H z}$ \\
\hline Male Worker & 25 & 35 & 40 \\
1. Current Audiogram (Age 48 years) & 10 & 15 & 20 \\
2. Baseline Audiogram (Age 47 years) & $(8)$ & $(14)$ & $(20)$ \\
3. Age Correction for Age 48 & $(8)$ & $(14)$ & $(19)$ \\
4. Age Correction for Age 47 & 0 & 0 & 1 \\
5. Diff Aging & 25 & 35 & 40 \\
Current Audiogram (Age 48) & 0 & 0 & 1 \\
Diff Aging & 25 & 35 & 39 \\
6. Current Audiogram(Age Corrected) & 25 & 35 & 39 \\
Current Audiogram(Age Corrected) & 10 & 15 & 20 \\
Baseline Audiogram (Age 47) & 15 & 20 & 19 \\
& & 18 & \\
7. STS & & &
\end{tabular}

\section{Appendix 3}

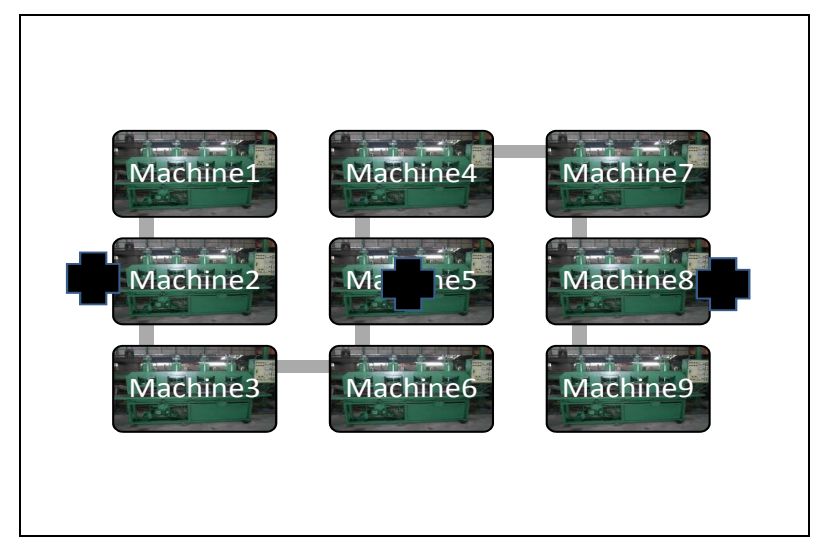

Figure 2. The pattern of noise monitoring in the production process; $\bar{c}$ = sound level meter point for monitoring the noise level. 